\title{
White Shrimp Litopenaeus vannamei Based Agroindustry Through Recirculating Aquaculture System \\ to Increase Competitiveness
}

\author{
Ridwan Latif Fauzi ${ }^{1}$, Agung Putra Pamungkas ${ }^{1}$ and Didik Purwadi ${ }^{1, *}$ \\ ${ }^{1}$ Departement of Agroindustrial Technology, Universitas Gadjah Mada Yogyakarta, Indonesia
}

\begin{abstract}
White shrimp is one of potential aquaculture products and economically valuable. Because of the business prospect, a lot of fish farmers take place the agroindustry as well as providing white shrimp cultivation. Recirculation Aquaculture System (RAS) is a method for cultivating white shrimp in order to increase the production of shrimp in limited aquaculture environment. The purpose of this study is to discuss how to increase competitiveness of agroindustry based white shrimp culture. In order to increase white shrimp culture competitiveness there are two ways should be provided: introduction RAS cultivation technology, and RAS cultivation management. This study obtained the result that indicates RAS cultivation technology can be applied for white shrimp fish farmers with optimum density is $400 \mathrm{shrimp} / \mathrm{m}^{3}, 1.13$ of Feed Conversion Ratio (FCR) and $70 \%$ of Survival Rate (SR). Industrial management should be considered to support aquaculture such as product, raw material, cultivation process, marketing, and financial.
\end{abstract}

\section{Introduction}

The cultivation of white shrimp in Yogyakarta is getting bigger since the opportunity of white shrimp as one of the leading commodities which has high selling price and market share. White shrimp cultivation without enough knowledge of Good Aquaculture Practices (GAP) tends to decrease quality of product and environment. This phenomenon gives serious impact to develop white shrimp cultivation.

The cultivation of white shrimp is still facing some problems. The main problems are the issues of environmental and lack of land availability. White shrimp has low competitiveness due to relatively wide land needs, that the main constraint is lack of sufficient land. Land availability for white shrimp cultivation should be suitable to Yogyakarta Special Region Government Planning. [1] described that the decline in white shrimp farming land is influenced by conversion of cultivation land into residential area and industrial estate development.

Agroindustry based-white shrimp culture also gives negative impact for environment. In order to avoid such environmental issues, the farmers should apply for GAP. Moreover, [2] explained that GAP application in white shrimp farming in Yogyakarta is $62.24 \%$. It means that $37.76 \%$ the practices are still out of standard. The cultivation technology to get optimum

*Corresponding authors: didik@ugm.ac.id

(C) The Authors, published by EDP Sciences. This is an open access article distributed under the terms of the Creative Commons 
FCR, SR, and density are remaining problem. RAS becomes an alternative to solve those problems.

White shrimp cultivation in Yogyakarta is mainly located in southern part such in Bantul District and Kulonprogo District. The farmers develop an association of shrimp farmer with the main purposes is to develop better GAP application for better production. It is in line with the policy of Yogyakarta Special Region Government that using 4K approach. The approach means that 4 stakeholders should be involved in production development. They are: (1) Kraton (Royal Palace), (2) Kampus (University), (3) Kaprajan (Regional Government), and (4) Kampung (The farmers).

The purpose of this paper is to discuss and develop on how to increase competitiveness of white shrimp business through $4 \mathrm{~K}$ approach. This paper will provide a guidance for GAP implementation for white shrimp business and give an insight of white shrimp cultivation management.

\section{Materials and Methods}

\subsection{Materials}

This research was conducted by using two types of data, primary and secondary data. The data are collected by field observation using a document investigation, focus group discussion by interview and questionnaire. Primary data was collected through observation and discussion with white shrimp farmers in Samas, Srigading, Sanden, and Bantul area together with the representatives from Kasultanan Ngayogyakarta Hadiningrat Palace, University, and Yogyakarta Special Region Government Office. Secondary data were collected from previous research report, journal, and statistical data from the government.

\subsection{Research Method}

This research was conducted through a systematic descriptive qualitative approach. It started with identifying the real problems and challenges of white shrimp cultivation through stakeholder Focus Group Discussion (FGD) approach. The result from the FGD then analyzed to be applied in RAS cultivation technology and RAS cultivation management for farmers. RAS cultivation technology was done through statistical experiments with density 200, 300, 400, and 500 shrimps $/ \mathrm{m}^{3}$. Parameters to be measured are daily growth rate, SR, and FCR. RAS cultivation management was done through functions of industrial approach, they are: product design, raw material management, transformation process, marketing, industrial relations, and internal management.

\subsection{Data Analysis}

Data analysis was conducted to identify the facts, to formulate the problems, to get to the business process of white shrimp cultivation, and to develop its competitiveness. Figure 1 described the framework of how to increase white shrimp competitiveness. The data then analyzed through descriptive qualitative. 


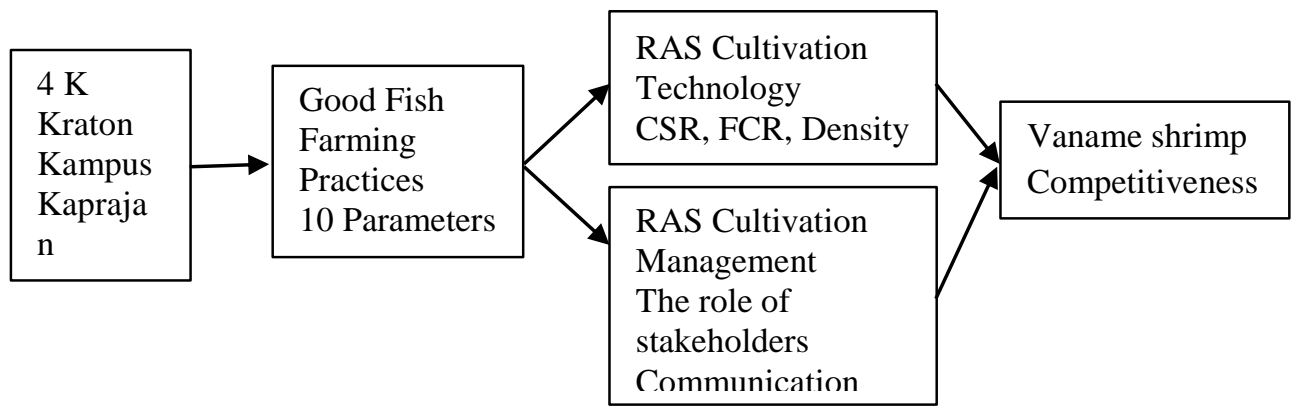

Fig. 1. Increasing Competitiveness Framework

\section{Result and Discussion}

\subsection{The importance of GAP implementation.}

To increase the competitiveness of white shrimp culture in Yogyakarta means to solve the main problems which are: the availability of land and environmental issues. Based on fish farmers practices, there are three ways to cultivate white shrimp: (1) traditional way with different shrimp size and low SR; (2) semi-intensive way with cultural development and selffeed production; and (3) intensive way with various aquaculture technology. RAS cultivation belongs to the intensive way. RAS cultivation technology needs only less size of land. It is also easier to control in environmental wise. RAS cultivation technology certainly needs farmers to apply the GAP requirements.

Moreover, [2] explained that the implementation of GAP for white shrimp in Yogyakarta is now reach up to $62.24 \%$. The GAP requirements cover 10 parameters: site selection, construction lay-out and design, selection aquaculture site/method, biosecurity, fingerlings selection, shrimp feed management, the use of the probiotic, the use of disinfectant, harvesting method, and harvesting equipment. Theoretically, white shrimp competitiveness will increase if fish farmers implement all of 10 parameters during the rearing period.

\subsection{RAS Cultivation Technology}

As described above that RAS is one of the intensive aquaculture techniques to solve the land availability problem. [3] concluded that the production of white shrimp cultivation can be conducted through semi-intensive or intensive system as well as RAS cultivation technology. The advantages of using RAS can be described by comparing with some various white shrimp cultivation technologies. [4] described that white shrimp aquaculture can be conducted by different cultivation technology in 4 kinds of ponds. Pond 1 is intensive pond with the same spot for inlet and outlet and using blower aerator. Pond 2 is using water changing and giving vitamin during the cultivation period. Pond 3 is semi-floc with probiotic application. Pond 4 is biofloc technology which zero waste system that is no change of water during the rearing period. It can be concluded that the growth of shrimp performance depends on the cultivation technology applied. Survival Rate and FCR can be different depending on the cultivation technology. The application of RAS cultivation technology in Yogyakarta can be explained in Fig. 2. 


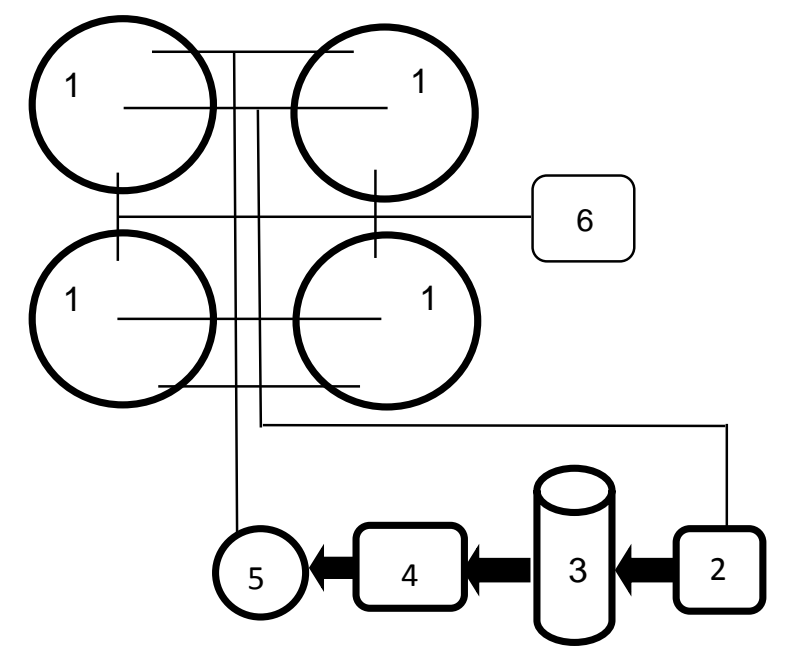

1. Portable pond

2. Filter

3. Protein skimmer

4. Bio-ball

5. Water reservoir

6. Aerator (blower)

Fig. 2. RAS as intensive way of cultivation

Figure 2 describes that there are 4 tanks with density of 200, 300, 400, and $500 \mathrm{shrimp} / \mathrm{m}^{3}$. RAS cultivation is designed with filter and using protein skimmer. Table 1 shows the result of SR based on the experimental research with various densities. It said that the best SR is $73.51 \%$ for $300 \mathrm{shrimp} / \mathrm{m}^{3}$ of density.

Table 1. Survival Rate (SR)

\begin{tabular}{|c|c|c|c|c|c|}
\hline No & $\begin{array}{l}\text { Density } \\
\left(\text { tails } / \mathrm{m}^{3}\right)\end{array}$ & 1 & 2 & 3 & Average \\
\hline 1 & 200 & $46.93 \%$ & $70.39 \%$ & $68.21 \%$ & $61.84 \%$ \\
\hline 2 & 300 & $76.35 \%$ & $73.00 \%$ & $71.17 \%$ & $73.51 \%$ \\
\hline 3 & 400 & $70.39 \%$ & $72.54 \%$ & $69.05 \%$ & $70.66 \%$ \\
\hline 4 & 500 & $50.68 \%$ & $49.16 \%$ & $54.08 \%$ & $51.31 \%$ \\
\hline
\end{tabular}

Table 2 shows the result of FCR based on the experimental research with various density. The FCR is vary from 1.11 to 1.26 in average, and it can be shown that more in density, it will decrease in FCR due to the variation of feed itself.

Table 2. Feed Conversion Ratio (FCR)

\begin{tabular}{|c|c|c|c|c|c|}
\hline No & $\begin{array}{l}\text { Density } \\
\left(\text { tails } / \mathrm{m}^{3}\right)\end{array}$ & 1 & 2 & 3 & Average \\
\hline 1 & 200 & 1.32 & 1.12 & 1.15 & 1.20 \\
\hline 2 & 300 & 1.11 & 1.12 & 1.18 & 1.14 \\
\hline 3 & 400 & 1.12 & 1.10 & 1.12 & 1.11 \\
\hline 4 & 500 & 1.22 & 1.38 & 1.18 & 1.26 \\
\hline
\end{tabular}

Based on the research result above, it can be described that RAS cultivation technology is feasible to be applied in order to assure the availability of white shrimp production.

\subsection{RAS Cultivation Management}

White Shrimp cultivation through RAS needs an industrial management, which comprises of 6 functions: product, raw material, production, marketing, industrial relations, and internal management (finance). 
Table 3. Industrial function criteria for RAS white shrimp cultivation

\begin{tabular}{|c|l|l|}
\hline No & \multicolumn{1}{|c|}{ Industrial Function } & \multicolumn{1}{|c|}{ Finding } \\
\hline 1 & Product design & $\begin{array}{l}\text { Fish farmers use white shrimp standard as their main } \\
\text { products. }\end{array}$ \\
\hline 2 & Raw material & $\begin{array}{l}\text { Fish farmers have a good supply chain management } \\
\text { with shrimp fry and feed producers. So that shrimp fry } \\
\text { and feed are always available. }\end{array}$ \\
\hline 3 & Production Process & $\begin{array}{l}\text { Fish farmers cultivate white shrimp as business as } \\
\text { usual. It needs wide land and give impact of } \\
\text { environmental issues. }\end{array}$ \\
\hline 4 & Industrial relation & $\begin{array}{l}\text { Management and workers relationship can be } \\
\text { managed through best communication with 4K } \\
\text { stakeholders. }\end{array}$ \\
\hline 5 & Marketing & $\begin{array}{l}\text { Fish farmers do not have enough knowledge and } \\
\text { experience how to market white shrimp, except they } \\
\text { sell through Surabaya, Sidoarjo, or Banyuwangi in } \\
\text { East Java exporters. }\end{array}$ \\
\hline 6 & Financial management & $\begin{array}{l}\text { Financial analysis indicates that it is feasible to be } \\
\text { developed. }\end{array}$ \\
\hline
\end{tabular}

Based on the Table 3 above, it can be concluded that all of 6 functions are important to assure the white shrimp RAS cultivation. Moreover [5] described that RAS is feasible to be developed but sensitive to changes in price, operation cost and production quantity.

Feeding management was applied through determining feeding management and feeding time, which described is Table 4. It also should maintain the water quality standard such as temperature, Dissolved Oxygen (DO), and pH. Finally, the harvest management should be applied with indicators mentioned in Table 1 and Table 2.

Table 4. Feeding management

\begin{tabular}{|c|c|c|c|c|c|c|}
\hline Age (days) & Amount (\%) & \multicolumn{5}{|c|}{ Feeding Time } \\
\hline $0-15$ & $15-20$ & 07.00 & 12.00 & 17.00 & & \\
\hline $16-30$ & $8-15$ & 06.00 & 10.00 & 14.00 & 18.00 & \\
\hline Up to 30 & $6-8$ & 06.00 & 09.00 & 12.00 & 15.00 & 18.00 \\
\hline
\end{tabular}

White shrimp cultivation management also considers the financial feasibility. The feasibility analysis of white RAS cultivation indicates that it is feasible with $\mathrm{B} / \mathrm{C}$ ratio 1.56 , IRR $32.66 \%, \mathrm{R} / \mathrm{C}$ ratio 1.49 with net profit/year up to $\mathrm{Rp} 7.004 .770$. This result is in line with [6] described that white Shrimp cultivation is feasible with B/C ratio 2.0.

\section{Conclusion}

In order to increase white competitiveness, there are two ways should be provided: introduction RAS cultivation technology, and RAS cultivation management. Based on the results of experiments that RAS cultivation technology can be applied for fish farmers with optimum density $400 \mathrm{shrimp} / \mathrm{m}^{3}, 1.13$ of FCR and $70 \%$ of SR. Industrial management should be considered such as product, raw material, cultivation process, marketing, and financial.

\section{References}

1. F. Mas'ud, and T. Wahyudi, Business Analysis of White Shrimp (Litopenaeus vannamei) Fresh Water Aquaculture in the Round Pool with Recirculation System, Jurnal Sumberdaya Indopasifik, 2, No 2 : 103-108, (2018) 
2. L. R. Nugroho, Sukardi, and B. Triatmo, Application of Good Farming Practice for Vaname Shrimp (Litopenaeus vannamei) in the Coastal of Yogyakarta, Jurnal Perikanan Universitas Gadjah Mada, 18 (2): 47-53, (2018)

3. S. Arsad, M. Musa, E. D. Lusiana, M. Mahmudi, N. R. Buwono, and G. Bintoro, Community Empowerment to Increase Litopenaeus vannamei Productivity Towards Semi-Intensive System by Potential Analysis and Self Feed Production, Agrokreatif, 4 (2) : 156-164 (2018)

4. S. Arsad, A. Afandy, A. P. Purwadhi, Betrina Maya V., D. K. Saputra, and N. R. Buwono, Study of Vannamei Shrimp Culture (Litopenaeus vannamei) In Different Rearing System, Jurnal Ilmiah Perikanan dan Kelautan, 9 (1) : 1-14, (2017)

5. Bijo, Pada Anak., Feasibility Study of Recirculation Aquaculture System, Final Project, Malaysian Fisheries Development Authority, 2007

6. P. Makalingga, A. Suryantini, and L. R. Waluyati, Financial Feasibility of Vannamei Shrimp Farming Business in the Purworejo Regency, Agro Ekonomi, 29 (2): 274-286, (2018)

7. L. A. Helfrich, and G. Libey, Fish Farming in Recirculating Aquculture Systems (RAS), Virginia Tech, http://fisheries.tamu.edu/files/2013/09/Fish-Farming-in-ResirculationAquaculture-System-RAS.pdf, (2013)

8. Anonimus, Recirculation Aquaculture System, AquacultureID, http:// www.aquacultureid.com/wp-content/uploads/2018/12/Dubai-Tilapia-RAS-Grow-Out1.jpg, (2018) 